\title{
Newcastle Disease Virus Detection from Chicken Organ Samples Using Reverse Transcriptase Polymerase Chain Reaction
}

\author{
Deteksi Virus Newcastle Disease dari Sampel Organ Ayam dengan Reverse Transcriptase \\ Polymerase Chain Reaction
}

\author{
Lehgarubini Shanmuganathan', Dito Anggoro², Michael Haryadi Wibowo² \\ ${ }^{1}$ Faculty of Veterinary Medicine, Gadjah Mada University, Yogyakarta \\ ${ }^{2}$ Department of Microbiology, Faculty of Veterinary Medicine, Gadjah Mada University, Yogyakarta \\ Email: lehgarubinishan@gmail.com¹, and mhwibowo@ugm.ac.id²
}

\begin{abstract}
Newcastle disease (ND) is a systemic, viral respiratory disease that is acute and easily transmitted which affects various types of poultry, especially chickens. Diagnosis of ND which generally involves virus isolation and subsequent identification with serological assays has limitations that needs more time. This research was aimed to detect Newcastle Disease virus (NDV) in chickens suspected with ND using the Reverse TranscriptasePolymerase Chain Reaction (RT-PCR) technique. Nine chicken organ samples such as lien, trachea, and lungs were collected from chicken farms diagnosed with ND. The organ samples were processed and the targeted viral RNA was extracted using the RNA extraction kit. Genome amplification was performed with RT-PCR using specific primers to target the $\mathrm{F}$ gene. Amplification results produced an amplicon product of 565 base pairs (bp). PCR product samples were then visualised using agar gel electrophoresis and viewed using the unified gel documentation system. Amplification results show nine samples positive for the DNA bands corresponding to the targeted band of the NDV F gene fragment. The results of this research confirm that the RT-PCR method is applicable for NDV detection from chicken organ samples.
\end{abstract}

Keywords: Newcastle Disease virus, organ sample, amplification.

\begin{abstract}
Abstrak
Newcastle Disease (ND) adalah suatu penyakit pernafasan dan sistemik, yang bersifat akut dan mudah menular, yang disebabkan oleh virus dan menyerang berbagai jenis unggas, terutama ayam. Diagnosis penyakit ND yang pada umumnya dilakukan dengan isolasi virus dan identifikasi serologis memiliki keterbatasan, antara lain diperlukan waktu yang lebih lama. Penelitian ini bertujuan mendeteksi virus Newcastle Disease (NDV) pada ayam yang dicurigai dengan penyakit ND dengan menggunakan teknik Reverse Transcriptase-Polymerase Chain Reaction (RT-PCR). Sembilan sampel organ ayam yaitu: lien, trakea, dan paru dikoleksi dari peternakan ayam yang didiagnosis penyakit ND. Sampel organ tersebut diproses dan diekstraksi RNA virus target dengan kit ekstraksi RNA. Amplifikasi genom virus dilakukan dengan RT-PCR menggunakan primer spesifik pada target gen F. Hasil amplifikasi menghasilkan produk amplikon sebesar 565 base pairs (bp). Sampel produk PCR kemudian divisualisasikan menggunakan gel elektroforesis dan diamati menggunakan unified gel documentation system. Hasil amplifikasi menunjukkan sembilan sampel positif teramati pita DNA sesuai target fragmen gen F virus ND. Hasil penelitian ini mengkonfirmasi bahwa metode RT-PCR dapat digunakan untuk mendeteksi virus ND dari sampel organ ayam.
\end{abstract}

Kata Kunci: virus Newcastle Disease, sampel organ, amplifikasi. 


\section{Introduction}

Newcastle disease (ND) is a systemic, respiratory disease that is acute and easily transmitted which is caused by a virus and affects various types of poultry, especially chickens (Tabbu, 2000). ND was first recognized in Indonesia in 1926 and classified as a viral disease (Alexander et al., 2004). The virus is endemic in most regions of the country as it has been isolated frequently in outbreaks (Dharmayanti et al., 2014; Wibowo et al., 2012). Wibowo et al. (2012) reports three types of Newcastle Disease virus (NDV) virulence found in the field, which are low, moderate, and virulent strains. According to Alexander (2003), the most virulent NDV strain is the Asiatic type which causes a $100 \%$ mortality rate in susceptible poultry, causing significant loss in Indonesia's poultry industry.

According to FAO (2010), poultry farming facilities throughout Indonesia range from backyard productions (sector 4) to high or low biosecurity commercial poultry production (sectors 2 and 3 ) to integrated, industrial productions (sector 1); with sector 2 commercial poultry productions dominating the national market. Regardless the level of biosecurity applied, all four sectors are in threat of Tetelo disease - local name for ND (Wibowo \& Amanu, 2010). This poses major problem to the nation as the disease is a sporadic epizootics despite implementation of routine vaccination programmes (Kryger et al., 2010). The consequences of the disease are low growth rate and production, high expense on prevention and treatment, and high mortality rate (Amanu \& Rohi, 2005).

The Office of Internationale des Epizooties (OIE) classified ND as list A disease (Alexander, 2000). According to OIE (1996), list A diseases are defined as "transmissible diseases that have the potential for very serious and rapid spread, irrespective of national borders, that are of serious socio-economic or public health consequence and that are of major importance in the international trade of animals and animal products." The virus belongs to the genus of Avulavirus and Paramyxoviridae family. It has an enveloped, non-segmented, negativesense, single stranded RNA genome that encodes six proteins (Rabalski et al., 2014; Shirvan \& Mardani, 2014). Avian paramyxovirus type 1 (APMV-1) or ND is a virus that occurs in filamentous or spherical forms (pleomorphic) and consists of a single molecule of negative sense, single-stranded RNA enclosed in an envelope with prominent glycoprotein spikes (MacLachlan \& Dubovi, 2010).

The RNA genome is about $15-18 \mathrm{~kb}$ in size and can consist up to at least three genome lengths; 15,186, 15,192 and 15,198 nucleotides (Miller et al., 2010). These nucleotides make up six genes which encode the following six structural proteins: nucleocapsid protein $(\mathrm{NP} / \mathrm{N})$, phosphoprotein $(\mathrm{P})$, matrix protein $(\mathrm{M})$, fusion protein $(\mathrm{F})$, haemagglutinin-neuraminidase (HN) and large protein (L) in the order of 3'leader-N-P-M-F-HNL-5 'trailer (Kho et al., 2003). Two additional nonstructural proteins (V and W) may be present in some strains; they are encoded by RNA editing of the P protein. Each protein functions differently to aid the infectivity and virulence of NDV. The F and HN proteins are anchored in the virion envelop and form the envelope spikes.

These proteins work together in the attachment and fusion of the virion to the host cell (MacLachlan \& Dubovi, 2010). Both F and HN proteins contribute to the virulence characteristic of 
NDV, but the primary determinant is the cleavability of the F protein (Cattoli et al., 2011). The F protein is synthesized as an inactive precursor (F0) and is only fusogenic after cleavage into two biologically active F1 and F2 polypeptide subunits, by host cell proteases (de Leeuw et al., 2005). The cleavage site of the $\mathrm{F}$ protein differs in arrangement of multiple basic amino acids depending on the degree of virulence.

Miller et al. (2010) distinguish lentogenic, mesogenic and velogenic strains as the three major pathotypic manifestations of NDV. The viscerotropic-velogenic NDV results in acute lethal infections, the neurotropic-velogenic NDV causes respiratory and neurological disease, while the mesogenic NDV is characterized by respiratory and neurological signs, but causes low mortality. NDV is highly contagious, with reports stating that even low pathogenic viral strains (lentogens) that cause mild infections of the respiratory tract can greatly increase its pathogenicity even during a single passage (Rabalski et al., 2014).

A definitive diagnosis of ND requires virus isolation and subsequent laboratoric characterization. Virus isolation is carried out by injecting and incubation antibiotic suspensions of samples retrieved from live birds into the allantoic cavity of embryonated chicken eggs. After the incubation period, the allantoic fluid is then harvested and tested (Alexander et al., 2004). Clinical signs and lesions may be highly suggestive; however this method proved impracticable as a routine tool (Haque et al., 2010). Instead conventional techniques such as agar gel precipitation test (AGPT), haemagglutination (HA) and haemagglutination inhibition (HI) tests were employed to assess antibody levels in birds. The AGPT has been found to be simple, inexpensive and faster in assessing ND infection in birds, nevertheless at present the $\mathrm{HI}$ test is most widely used technique (Alexander et al., 2004).

Common use of vaccines in domestic poultry limits the value of these assays; hence molecular techniques such as reverse transcription-polymerase chain reaction (RT-PCR) were applied to detect NDV in clinical specimens (OIE, 1996). The RTPCR method is superior to other NDV confirmatory diagnostic methods (Singh et al., 2005). This method uses a gene-specific primer to generate singlestranded cDNA copies of NDV RNA gene, with the help of reverse transcriptase (RT) enzyme. The cDNA copies are used as PCR templates to produce exponential amplification of the viral nucleic acids, even if it is present in small amounts (Rio et al., 2011).

The analysis study on NDV isolates by Angeliya et al. (2014) was able to detect NDV in samples successfully by using primers targeting the F gene. The research by Haque et al. (2010) used specific primers which amplified a 356 bp long F gene sequence encoding the fusion protein cleavage site. Likewise, Singh et al. (2005) used primers targeting the internal sequences of the NDV F gene cleavage activation. The results showed that RT-PCR targeting could be effectively used for NDV detection.

The RT-PCR was carried out in the Laboratorium of Microbiology, Fakultas Kedokteran Hewan, Universitas Gadjah Mada. The aim of this study is to detect NDV in organ samples such as lien, trachea, and lungs collected from vaccinated chickens that NDV-suspected using RT-PCR. Research benefits are to learn whether RT-PCR is applicable for ND detection from NDV-suspected chicken organ samples. 
Table 1. Data of organ samples of chicken suspected to NDV infection which be used in this research.

\begin{tabular}{|c|c|c|c|c|c|}
\hline No. & $\begin{array}{l}\text { Sample ID code and } \\
\text { collection area }\end{array}$ & $\begin{array}{c}\text { Chicken } \\
\text { age }\end{array}$ & Farming system & Clinical signs & $\begin{array}{l}\text { Sample } \\
\text { type }\end{array}$ \\
\hline 1. & $\begin{array}{l}\text { GK-1 } \\
\text { SR Farm/2013 } \\
\text { (Semanu, Gunungkidul, } \\
\text { Yogyakarta) }\end{array}$ & 48 weeks & $\begin{array}{l}\text { Layer farm, vaccination: } \\
\text { Week 16: Triple vaccine ND-IB- } \\
\text { EDS } \\
\text { Revaccination every } 1.5 \text { months }\end{array}$ & $\begin{array}{l}\text { Drop in } \\
\text { production and } \\
\text { greenish diarrhea }\end{array}$ & Pulmo \\
\hline 2. & $\begin{array}{l}\text { KP-1 } \\
\text { PR Farm/2013 } \\
\text { (Kulonprogo, Yogyakarta) }\end{array}$ & 7 weeks & $\begin{array}{l}\text { Layer farm, vaccination: } \\
\text { Day 5: ND-IB live and ND killed } \\
\text { Day 18: ND live } \\
\text { Day 35: ND live }\end{array}$ & $\begin{array}{l}\text { High mortality } \\
\text { and torticollis }\end{array}$ & Pulmo \\
\hline 3. & $\begin{array}{l}\text { BYL-1 } \\
\text { RH Farm/2014 } \\
\text { (Boyolali, Central Java) }\end{array}$ & 10 weeks & $\begin{array}{l}\text { Layer farm, vaccination: } \\
\text { Day 1: ND-IB live } \\
\text { Day 5: ND-IB killed } \\
\text { Day 49: ND live }\end{array}$ & $\begin{array}{l}\text { High mortality, } \\
\text { torticollis, and } \\
\text { greenish diarrhea }\end{array}$ & Pulmo \\
\hline 4. & $\begin{array}{l}\text { SEM-1 } \\
\text { GK Farm/2015 } \\
\text { (Semin, Gunungkidul, } \\
\text { Yogyakarta) }\end{array}$ & 3 weeks & $\begin{array}{l}\text { Broiler farm, vaccination: } \\
\text { Day 4: ND-IB live and ND killed }\end{array}$ & High mortality & Pulmo \\
\hline 5. & $\begin{array}{l}\text { SEM-2 } \\
\text { GK Farm/2015 } \\
\text { (Semin, Gunungkidul, } \\
\text { Yogyakarta) }\end{array}$ & 3 weeks & $\begin{array}{l}\text { Broiler farm, vaccination: } \\
\text { Day 4: ND-IB live and ND killed }\end{array}$ & High mortality & Pulmo \\
\hline 6. & $\begin{array}{l}\text { SEM-3 } \\
\text { GK Farm/2015 } \\
\text { (Semin, Gunungkidul, } \\
\text { Yogyakarta) }\end{array}$ & 3 weeks & $\begin{array}{l}\text { Broiler farm, vaccination: } \\
\text { Day 4: ND-IB live and ND killed }\end{array}$ & High mortality & Lien \\
\hline 7. & $\begin{array}{l}\text { WNgiri-1 } \\
\text { SCI Farm/2015 } \\
\text { (Wonogiri, Central Java) }\end{array}$ & 4 weeks & $\begin{array}{l}\text { Broiler farm, vaccination: } \\
\text { Day 4: ND-IB live and killed } \\
\text { Day 21: ND live vaccine }\end{array}$ & High mortality & Pulmo \\
\hline 8. & $\begin{array}{l}\text { BRAH-2 } \\
\text { JH Farm/2014 } \\
\text { (Brahrang, North } \\
\text { Sumatera) }\end{array}$ & 10 weeks & $\begin{array}{l}\text { Layer farm, vaccination: } \\
\text { Day 1: ND-IB live } \\
\text { Day 14: ND-IB killed } \\
\text { Day 20: ND live }\end{array}$ & $\begin{array}{l}\text { High mortality } \\
\text { and torticollis }\end{array}$ & Trachea \\
\hline 9. & $\begin{array}{l}\text { BRAH-1 } \\
\text { JH Farm/2014 } \\
\text { (Brahrang, North } \\
\text { Sumatera) }\end{array}$ & 6 weeks & $\begin{array}{l}\text { Layer farm, vaccination: } \\
\text { Day 1: ND-IB } \\
\text { Day 14: ND-IB killed } \\
\text { Day 20: ND-IB live }\end{array}$ & $\begin{array}{l}\text { High mortality } \\
\text { and torticollis }\end{array}$ & Pulmo \\
\hline
\end{tabular}

\section{Materials and Method}

A total of nine organ samples (trachea, lien and pulmo) used in this research were provided by Dr. drh. Michael Haryadi Wibowo, M.P.. The samples were collected from vaccinated broiler or layer chickens showing clinical signs from farms in Brahrang, Gunung Kidul, Kulon Progo, Boyolali, and Wonogiri. All farms were applying intermediate 
biosecurity programs and have no record of ND outbreaks. Data on the chicken organ samples is described in Table 1.

$1 \mathrm{ml}$ of Virus Transport Medium (VTM) was transferred into the mortar and a small portion of the organ sample was placed in the mortar, then homogenized and labelled. The samples were treated with the QIAamp ${ }^{\circledR}$ RNA kit for viral RNA extraction and purification, followed by elusion. The final RNA extraction samples were immediately sequenced with RT-PCR, with the use of a mastermix solution and the T100 ${ }^{\mathrm{TM}}$ Thermal Cycler PCR machine. The PCR program as shown in Table 2 was keyed into the machine to process the samples.

The final step involves visualisation of the RTPCR product samples in agarose gel electrophoresis. The GeneRuler 100bp DNA Ladder and a positive control with the same size fragment as potential positive samples was used to measure and detect sample bands produced. The results were viewed and documented with the Unified Gel Documentation System.

Table 2. RT-PCR Program

\begin{tabular}{lcc}
\hline \multicolumn{1}{c}{ Process } & $\begin{array}{c}\text { Temperature } \\
\left({ }^{\circ} \mathrm{C}\right)\end{array}$ & Time \\
\hline RT reaction & 50 & 30 minutes \\
Pre-denaturation & 95 & 5 minutes \\
Denaturation & 95 & 15 seconds \\
Annealing & 55 & 45 seconds \\
Elongation & 72 & 60 seconds \\
\hline
\end{tabular}

\section{Results and Discussion}

This research applied RT-PCR technique to detect the presence of NDV genome in chickens organ samples suspected with NDV. RT-PCR results are summarised in Table 3 and Figure 1.
In Table 3, the RT-PCR results were recorded as positive with a '+' sign, and negative with a '-' sign, and both positive and negative controls serve as reference. The La Sota live ND vaccine used as the positive control contains the targeted $565 \mathrm{bp}$ NDV genome and GeneRuler 100bp DNA Ladder helps estimate the size of the nucleotides separated and detect whether the desired gene sequence was amplified.

Band formations along lanes 2 to 10 in Figure 1 indicate all nine samples are NDV positive. Formation of sharp bands indicates optimal RT-PCR program and materials were applied in this research to produce good quality amplification products. Results show that samples bands formed within the $500 \mathrm{bp}$ to 600 bp range which suggests the presence of the targeted 565 bp NDV F gene fragment in all nine samples. Pelt-Verkuil et al. (2008) states that comparing band intensities of sample bands to a control of known quantity, such as the DNA ladder, helps yield a measure of the amount of transcript in the samples. Hence, difference in band intensities corresponds to the amount of virus present in samples. Difference in sample band thickness may be used to estimate the amount of product relative to the DNA ladder.

Samples 1 and 2 (lane 2 and 3 respectively) have bands similar in width to the positive control but thinner compared to other samples. Meanwhile, samples 3 to 6 (lanes 4 to 7) and samples 8 and 9 (lanes 9 and 10 respectively) have a bands that are thicker in size. Hence, results suggest that samples 3 to 9 have higher amounts of $\mathrm{F}$ gene fragments compared to samples 1 and 2. Sample band7 with the thickest band formation (along lane 8) 
Table 3: RT-PCR Results

\begin{tabular}{cllcc}
\hline No & Sample Code & Organ Sample & Lane & Results \\
\hline 1. & BRAH-2/2014 & Trachea & 2 & + \\
2. & SEM-1/2015 & Pulmo & 3 & + \\
3. & SEM-2/2015 & Pulmo & 4 & + \\
4. & SEM-3/2015 & Lien & 5 & + \\
5. & KP-1/2013 & Pulmo & 6 & + \\
6. & GK-1/2013 & Pulmo & 7 & + \\
7. & BYL-1/2014 & Pulmo & 8 & + \\
8. & BRAH-1/2014 & Pulmo & 9 & + \\
9. & WNgiri-1/2015 & Pulmo & 10 & + \\
10. & Live ND Vaccine (La Sota) & Positive control & $\mathrm{K}+$ & - \\
11. & Nuclease Free Water & Negative control & $\mathrm{K}-$ & + \\
\hline
\end{tabular}

Positive result: '+', Negative result: '-’.

\section{has the highest amount of $F$ gene fragments.}

Molecular identification in this study was based on the amplification of NDV F gene fragment at position 71 to 635 with a product size of $565 \mathrm{bp}$ with the use of primers designed by the Lampung Disease Investigation Centre (Angeliya et al., 2014). Both those primers, namely: forward primer (5' GCT-GTA-TCT-GTC-TGA-CAA-GCT-CTC 3') and reverse primer (5'AGG-TTG-AGT-TCT-ACA-CCAACC-TGT 3') have motives specific to the target site. NDV detection with RT-PCR primarily targets the F gene because NDV virulence is principally dependent on the amino acid sequence at the F0 cleavage site (Alexander, 2000). In comparison, Dharmayanti et al. (2014) applied another set of primers to target different portion of the $\mathrm{F}$ gene with a $535 \mathrm{bp}$ product
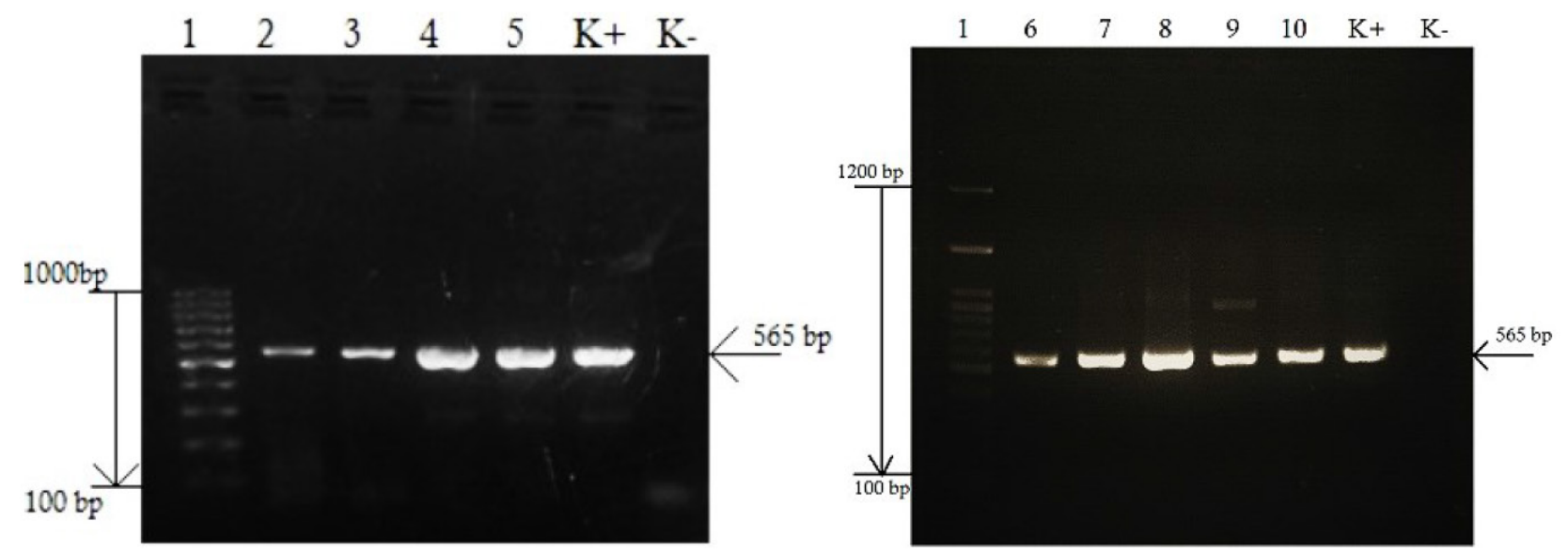

Figure 1: Amplification results of the targeted 565 bp long NDV genome. Lane 1 contains the 100bp DNA Ladder. Lanes 2, 3, 4, 5, 6, 7, 8, 9, and 10 containing the samples showed positive amplification results. Lane $\mathrm{K}+$ is the positive control and lane $\mathrm{K}$ - is the negative control. 
size. The research by Haque et al. (2010) used specific primers which amplified a 356 bp long $\mathrm{F}$ gene sequence encoding the fusion protein cleavage site. Likewise, Singh et al. (2005) used the same primers for the $356 \mathrm{bp}$ amplicon, along with another pair of primers targeting the $216 \mathrm{bp}$ internal sequences of the NDV F gene cleavage activation. Results from these studies show that RT-PCR amplification applying F gene as the target sequence to be effective for NDV detection. NDV sequencing using RT-PCR has been established as an effective method, especially after prior isolation and serology tests as prescribed by the OIE Standards Commission (Oberdorfer \& Werner, 1998). A research by Kencana et al. (2012) used this technique for confirmatory diagnosis of ND in native Bali chickens. Kencana (2012) carried out propagation of samples in embryonated chicken eggs and subsequent confirmatory serology tests prior to RT-PCR amplification. The same method was reported by Dharmayanti et al. (2014).

However, in this research RT-PCR was performed to detect NDV directly from chicken organ samples. According to Kant et al. (1997) found direct RT-PCR detection from organ samples containing virulent NDV to be possible, but failed to detect NDV in some tissue samples containing nonvirulent NDV due to the assay sensitivity. Another report by Gohm et al. (2000) states that rapid NDV detection is achieved by employing RT-PCR directly on samples from affected birds without prior virus isolation. These findings are in close agreement with the present study.

\section{Conclusion}

All nine samples were confirmed positive as NDV by RT-PCR using specific primers of targeted
F gene fragment and produced of 565 base pairs amplicon product. The result showed that this method could be used for NDV detection from chicken organ samples without prior isolation and propagation in embryonated eggs. Hence, the RT-PCR method is applicable for detection of NDV in chicken organ samples.

\section{Acknowledgement}

Part of this data is supported by USDA-ARS, USA, No.999x-14-60072-1.

\section{References}

Alexander, D.J. 2000. Newcastle disease and other avian paramyxoviruses. Revue Scientifique et Technique de L'Office International Des Epizooties 19(2): 443-462.

Alexander, D. Newcastle disease, other avian paramyxoviruses, and pneumovirus infections. In: Diseases of Poultry. Saif, Y.M., Barnes, H.J., Glisson, J.R., Fadly, A.M., McDougald, L.R., Swayne, D., (eds)., Iowa State University Press, Ames. 63-99.

Alexander, D.J., Bell, J.G. and Alders, R.G. 2004. A Technology Review: Newcastle Disease. FAO Animal Health and Production Paper, 161: 1-15.

Amanu, S. and Rohi, O.K. 2005. Studi Serologis dengan Uji Hambatan Hemaglutinasi terhadap Angsa yang dapat bertindak sebagai pembawa Newcastle Disease di D.I.Yogyakarta. Jurnal Sain Veteriner, 1: 8-12.

Angeliya, L. 2014. Analisis Phylogenic Tree Dan Konsensus Sequence Virus Newcastle Disease Isolat Asal Wilayah Kerja Balai Veteriner Lampung Tahun 2010-2013. In: Prosiding Seminar Nasional Sains dan Inovasi Teknologi Pertanian, Balai Pengkajian Teknologi Pertanian (BPTP), Lampung. 474-481.

Cattoli, G., Susta, L., Terregino, C., and Brown, C. 2011. Newcastle disease: a review of field recognition and current methods of laboratory 
detection. Journal of Veterinary Diagnostic Investigation, 23(4): 637-656.

de Leeuw, O.S., Koch, G., Hartog, L., Ravenshorst, N. and Peeters, B.P. H. 2005. Virulence of Newcastle disease virus is determined by the cleavage site of the fusion protein and by both the stem region and globular head of the haemagglutinin-neuraminidase protein. Journal of General Virology, 86: 1759-1769.

Dharmayanti, N.L.P.I., Hartawan, R., Hewajuli, D.A. and Indriani, R. 2014. Phylogenetic Analysis of Genotype VII of Newcastle Disease Virus in Indonesia. African Journal of Microbiology Research, 8(13): 1368-1374

Gohm, D.S., Thür, B. and Hofmann, M. A. 2000. Detection of Newcastle disease virus in organs and faeces of experimentally infected chickens using RT-PCR. Journal of Avian Pathology, 29(2): 143-152

Haque, M.H., Hossain, M. T., Islam, M. T., Zinnah, M. A., Khan, M. S. R. and Islam, M.A. 2010. Isolation and Detection of Newcastle Disease Virus From Field Outbreaks In Broiler And Layer Chickens By Reverse TranscriptionPolymerase Chain Reaction. Bangladesh Journal of Veterinary Medicine, 8(2): 87-92.

Kant, A., Koch, G., Van Roozelaar, D.J., Balk, F. and Ter Huurne, A. 1997. Differentiation of virulent and non-virulent strains of Newcastle disease virus within 24 hours by polymerase chain reaction. Avian Pathology Journal, 26(4): $837-849$

Kencana, G.A.Y., Kardena, I.M., and Mahardika, I.G.N.K. 2012. Diagnosis Confirmation of Newcastle Disease on Native Chicken in Bali Using RT-PCR Method. Jurnal Kedokteran Hewan, 6(1): 28-31

Kho, C.L., Tan, W.S., Tey, B.T. and Yusoff, K. 2003. Newcastle Disease Virus Nucleocapsid Protein. Journal of General Virology, 84: 2163-2168.

Kryger, K.N., Thomsen, K.A., Whyte, M.A. and Dissing, M. 2010. Smallholder Poultry Production. FAO Smallholder Poultry Production Paper. 4: 7-25.
MacLachlan, N.J. and Dubovi, E.J. (eds). 2010. Fenner's Veterinary Virology. 4th Edition., Academic Press Elsevier, London. 300, 304305, 311-314.

Miller, P.J., Decanini, E.L. and Afonso, C.L. 2010. Newcastle disease. Infection, Genetics and Evolution, 10(1): 26-35.

Oberdorfer, A. and Werner, O. 1998. Newcastle disease virus: Detection and characterization by PCR of recent German isolates differing in pathogenicity. Journal of Avian Pathology, 27(3): 237-243.

Office International des Epizooties (OIE). 1996. Manual of Standards for Diagnostic Tests and Vaccines. $3^{\text {rd }}$ Edition., OIE Manual, 161-165.

Office International des Epizooties (OIE). 2008. Manual of Diagnostic Tests and Vaccines for Terrestrial Animals. $6^{\text {th }}$ Edition., OIE Terrestrial Manual, 1: 576-582.

Pelt-Verkuil, E.V., Belkum, A.V., and Hays, J.P. 2008. Principles and Technical Aspects of PCR Amplification. Springer Science \& Business Media. 20.

Rabalski, L., Smietanka, K., Minta, Z., and Szewczyk, B. 2014. Detection of Newcastle Disease Virus Minor Genetic Variants by Modified SingleStranded Conformational Polymorphism Analysis. BioMed Research International, 2014(632347): 1-8.

Rio, D. C., Ares, M., Hannon, G.J. and Nilsen, T.W. 2011. RNA: A Laboratory Manual. Cold Spring Harbour Laboratory Press. New York. 17.

Saif, Y.M. 2011. Diseases of Poultry. 12 $2^{\text {th }}$ Edition., Iowa, John-Wiley and Sons Publishing Inc. 87-93.

Shirvan, A.S. and Mardani, K. 2014. Molecular Detection of Infectious Bronchitis and Newcastle Disease Viruses in Broiler Chickens with Respiratory Signs using Duplex RT-PCR. Veterinary Research Forum, 5(4): 319 - 323

Singh, K., Jindal, N., Gupta, S.L., Gupta, A.K. and Mittal D. 2005. Detection of Newcastle Disease Virus Genome from the Field 
Outbreaks in Poultry by Reverse Transcription - Polymerase Chain Reaction. International Journal of Poultry Science, 4(7): 472-475.

Tabbu, C.R. 2000. Penyakit Ayam dan Penanggulangannya: Volume 1. Penerbit PT Kanisius, Yogyakarta, 49-51.

Wibowo, M.H. and Amanu, S. 2010. Perbandingan beberapa Program Vaksinasi Penyakit Newcastle pada Ayam Buras. Jurnal Sain Veteriner, 28(1): 27-35.

Wibowo, M.H., Untari, T. and Wahyuni, A.E.T.H. 2012. Isolation, Identification, Physical, And Biological Character Of Newcastle Disease Virus Isolated From Field Cases. Jurnal Sain Veteriner, 13(4): 425-433. 